\title{
Sustainable Management of Sewage Sludge for the Production of Organo-Mineral Fertilizers
}

\author{
Halyna Kominko ${ }^{1} \cdot$ Katarzyna Gorazda $^{1} \cdot$ Zbigniew Wzorek $^{1} \cdot$ Katarzyna Wojtas $^{1}$
}

Received: 6 October 2016 / Accepted: 11 April 2017 / Published online: 18 April 2017

(C) The Author(s) 2017. This article is an open access publication

\begin{abstract}
Circular Economy (CE) package accepted by the European Union (EU) in December 2015 promotes close-loop flows of materials. The main targets provided in the documents refer to the prevention of waste landfilling, efficient use of resources and energy, as well as reuse waste and by-products. Sewage sludge-residue from Waste Water Treatment Plant (WWTP) - has a great fertilizer potential and should be recycled in line with the $\mathrm{CE}$ strategy. Sewage sludge usage for agricultural purposes seems to be the best sustainable option of its disposal. New EU regulations related to fertilizers derived from bio-waste and by-products assume the uniformity of legislation in Member States and simplification of procedures for introducing innovative fertilizers into the internal market. The characteristic of organo-mineral fertilizers obtained from dried sewage sludge is presented in the paper. In order to obtain balanced NPK fertilizers straight mineral fertilizers, poultry litter ash and phosphoric/nitric acids or a mixture of these were added. As a result organo-mineral fertilizers with $\mathrm{N}+\mathrm{P}_{2} \mathrm{O}_{5}+\mathrm{K}_{2} \mathrm{O}>20 \%$ were produced. It was found that the largest contribution of contaminants in products comes from Wet Process Phosphoric Acid.
\end{abstract}

Halyna Kominko

halynakominko@chemia.pk.edu.pl

Katarzyna Gorazda

gorazda@chemia.pk.edu.pl

Zbigniew Wzorek

wzor@chemia.pk.edu.pl

Katarzyna Wojtas

kwojtascz@gmail.com

1 Cracow University of Technology, Warszawska Str. 24, 31-155 Cracow, Poland
Keywords Sewage sludge · Organo-mineral fertilizers . Phosphorus recovery $\cdot$ Poultry litter ash $\cdot$ Sewage sludge management $\cdot$ Circular economy

\section{Introduction}

A lot of attention has been recently paid to sewage sludge disposal due to its increasing amount and tightened legislation in the EU referring to its final disposal methods. It is estimated that in the year 2020 approximately $13 \mathrm{~m}$ tonnes of sewage sludge will be generated in EU27 [1]. It is a challenge to sewage sludge management because of pollutants, including heavy metals [2,3], pathogenic and disease causing microorganisms and toxic compounds [4-6], which can occur in sewage sludge.

In last years a tendency for thermal methods of sewage sludge disposal has increased [7, 8]. Despite the advantages of thermal methods including significant reduction in volume as well as phosphorus and energy recovery, one fact should be taken into account: this disposal method is not in line with Circular Economy concerning cutting of $\mathrm{CO}_{2}$ emissions and nutrient recycling (especially organic compounds and nitrogen) [9].

The agricultural use of sewage sludge can be alternative for incineration method. The EU strongly promotes sewage sludge application to land. Due to the Circular Economy policy one of the key elements of resource-efficient and environment-friendly society is recycling, which allows to reduce cost and dependence on natural feedstocks, limit waste generation and stimulate economic growth [10]. From that point of view sewage sludge should be treated as secondary raw material and used as a valuable source of nutrients and organic matter. It is particularly important with reference to phosphorus which is limited $[11,12]$. 
Taking into account the expected global population growth [13] leading to food demand, we expect an increasing demand for fertilizers in coming years. Therefore it is necessary to use alternative resources which is sewage sludge. Phosphorus presented in sludge residue can cover about $20 \%$ of its demand [14].

According to Milieu Ltd report [1] in the EU 37\% of sewage sludge was recycled. The share of sewage sludge used for agricultural purposes varies from country to country. In Norway land recycling of sewage sludge is considered the most environmentally sustainable option of its disposal; more than $90 \%$ of sewage sludge is applied to soil [15]. The agricultural use of sewage sludge has also preference in France (nearly $60 \%$ of sewage sludge is applied to soil), Belgium (57\%), as well as in Spain, UK and Italy [1, 16]. Whereas in Denmark, Germany, Sweden and the Netherlands very strict limits have been established related to contaminants in sewage sludge intended for agricultural use [17] and there is no agreement for sewage sludge application to soil in Switzerland [7]. In Poland recycling sewage sludge to land is commonly used; in the year $201419 \%$ of sewage sludge was applied in agriculture, $8 \%$-in cultivation of plants intended for compost production and $4 \%$-in land reclamation [18].

The Sewage Sludge Directive 86/278/EEC [19] regulates sewage sludge recycling to land in a way to protect plants, soil and groundwater as well as to safeguard animal and human health. The directive lays down permissible concentration of heavy metals in sewage sludge and soil intended for sewage sludge application. The Member States may set more stricter limit values of heavy metals content in sewage sludge and soil [1]. The Sewage Directive as well as Urban Waste Water Directive [20] do not involve monitoring of organic contaminants in influents and sewage sludge. The question regarding setting the limit concentration for organic chemicals is complicated due to the lack of accepted analytical methods for their determination in sewage sludge and knowledge on the transformation of organic compounds [21]. Such countries as the USA, Canada and the UK claim that there is no need for setting limit values on emerging organic pollutants because their typical concentration in sewage sludge cannot pose a threat for environment and human health. However Germany, Sweden, Denmark, France, the Czech Republic and Hungary fixed allowable concentration of toxic organic compounds (PAH, PCB, dioxins, DEHP, alkyl sulphonates, nonylphenol) in sewage sludge [22]. The share of organic pollutants depends on a source of waste water and type of treatment to which sewage sludge was subjected [23]. The study showed that the concentrations of DEHP, LAS, NPE and PAH are higher in anaerobic digested dehydrated sludge in comparison with composted sludge, which can be caused by a slow degradation rate of these compounds under anaerobic conditions [24]. Degradation of pharmaceuticals (estrone, diclofenac, ibuprofen and carbamazepine) during composting with waste wood in UASB (upflow anaerobic sludge bed) was confirmed in [25]. Micropollutants were removed with rate ranging $99.9 \%$ for ibuprofen, diclofenac and estrone to $87.8 \%$ for carbamazepine. There are no differences in the degradation rate of pharmaceuticals under thermophilic and mesophilic conditions [26]. The analysis coming from study [17] showed that sewage sludge from small and medium waste water treatment plants was in compliance with criteria related to the content of some organic pollutants proposed by Working document on sludge (PCB- $0.8 \mathrm{mg} / \mathrm{kg} \mathrm{dsm}$, DEHP $-100 \mathrm{mg} / \mathrm{kg} \mathrm{dm}$, PAH- $6 \mathrm{mg} / \mathrm{kg} \mathrm{dm}$, AOX$500 \mathrm{mg} / \mathrm{kg} \mathrm{ds}$, LAS-2600 mg/kg dm and NPE- $50 \mathrm{mg} /$ $\mathrm{kg} \mathrm{dm}$ ) and can be used for soil application.

Because of a large number of emerging organic contaminants there is a need for future monitoring programmes and technological changes in sewage sludge management in order to reduce the concentration of organic contaminants to a level acceptable for sewage sludge application [27].

In order to decrease a harmful effect caused by micropollutants and heavy metals on the environment and human health and to improve sewage sludge management considering nutrients and organic matter recycling to soil, sewage sludge can be used as a component for fertilizers production, which allows to reduce the concentration of contaminants and fulfil the requirements. Fertilizers derived from bio-waste or by-products can bring economic and environmental benefits but they do not have free entry to the EU's internal market. The problem is connected with different legislations in Member States [28]. New regulations to boost the use of organic and waste-based fertilizers, proposed by the European Commission, allow organo-mineral fertilizers from biomass to be competitive with mineral fertilizers through harmonization of legislation. Besides providing free movement for waste-sourced fertilizers as the main element, the proposal also updates requirements for inorganic fertilizers, simplifies procedures and mechanisms for placing fertilizers on the market. The document also provides a high level of soil protection through determination of Cadmium content in fertilizers. The Commission proposes to set the limit of $\mathrm{Cd}$ at the level of $60 \mathrm{mg} /$ $\mathrm{kg} \mathrm{P}_{2} \mathrm{O}_{5}$ and this value will be tightened to $40 \mathrm{mg} / \mathrm{kg}$ after 3 years, and to $20 \mathrm{mg} / \mathrm{kg}$ after 12 years [29].

The low permissible value of $\mathrm{Cd}$ content in fertilizers will close the way of using sewage sludge from the biggest wastewater treatment plants for fertilizer production due to a high heavy metal content as a result of great share of industrial wastewater in total sewage flow. It will probably lead to an increase in prices of mineral fertilizers because of the limited occurrence of Cd-low phosphate rocks [30]. 
The quality of sewage sludge is continuously improving due to regulations and the current state of knowledge. That allows to control an extent of stabilization and sanitation of sewage sludge, which leads to more efficient reduction of pathogens and toxic compounds. The disposal of properly prepared sewage sludge to land should be considered as the most attractive option for sewage sludge management. Recycling programmes towards Circular Economy and new European regulations encourage sewage sludge agricultural use; it is a way of low-cost sludge utilization and possibility to return nutrients and organic matter to the soil.

In this work a method for organo-mineral fertilizers production based on sewage sludge was presented. A proper ratio of sewage sludge to other components in order to obtain OMF with low heavy metals content was investigated. The distribution of heavy metals and its origin in fertilizers composition was widely discussed. The simplified economic analysis was made.

\section{Materials and Methods}

Organo-mineral fertilizers (OMFs) were produced by adding to dry sewage sludge straight mineral fertilizers in order to increase a nutrient content and mineral acids as binding agents. Anaerobically digested sewage sludge obtained from Waste Water Treatment Plant in Kędzierzyn-Koźle (Poland) was used in the experiment. The contents of individual components of sewage sludge are presented in Table 1.

Potassium chloride, diammonium phosphate (DAP) and poultry litter ash were added as sources of potassium and phosphorus. Poultry litter ash is rich in potassium, as well as in phosphorus, calcium, magnesium and zinc (Table 1) and its application in fertilizer products could be a sustainable method of its disposal. Phosphoric acid (69-73\% $\mathrm{H}_{3} \mathrm{PO}_{4}$ ) from Polish industrial wet extraction plant was used and technical grade 55\% $\mathrm{HNO}_{3}$ (Brenntag Poland) were used in the experiment. The acids acted as a binding agent required for a mechanical granulation process.

The first step of research was intended to select such components of fertilizers and their amount which would allow to produce organo-mineral fertilizers complying with Polish requirements. According to Regulation of the Minister of Agriculture and Rural Development [31], organomineral fertilizers in solid state should contain at least $20 \%$ of organic matter, expressed as dry solids. The nutrients content cannot be less than:

a. $1 \%(\mathrm{~m} / \mathrm{m})$ of total nitrogen $(\mathrm{N})$;

b. $0.5 \%(\mathrm{~m} / \mathrm{m})$ of total phosphorus expressed as phosphorus pentoxide $\left(\mathrm{P}_{2} \mathrm{O}_{5}\right)$;
Table 1 Characterization of substrates (expressed as dry solids)

\begin{tabular}{|c|c|c|}
\hline & Sewage sludge & Poultry litter ash \\
\hline $\mathrm{P}_{2} \mathrm{O}_{5}(\%)$ & $\begin{array}{l}5.67 \\
\sigma=0.06\end{array}$ & $\begin{array}{l}18.1 \\
\sigma=0.78\end{array}$ \\
\hline $\mathrm{K}_{2} \mathrm{O}(\%)$ & $\begin{array}{l}0.218 \\
\sigma=0.27\end{array}$ & $\begin{array}{l}24.0 \\
\sigma=0.80\end{array}$ \\
\hline $\mathrm{N}(\%)$ & $\begin{array}{l}4.52 \\
\sigma=0.04\end{array}$ & - \\
\hline $\mathrm{Ca}(\%)$ & $\begin{array}{l}4.37 \\
\sigma=0.03\end{array}$ & $\begin{array}{l}14.3 \\
\sigma=0.89\end{array}$ \\
\hline $\operatorname{Mg}(\%)$ & $\begin{array}{l}0.66 \\
\sigma=0.02\end{array}$ & $\begin{array}{l}51 \\
\sigma=0.59\end{array}$ \\
\hline $\mathrm{Fe}(\%)$ & $\begin{array}{l}2.02 \\
\sigma=0.05\end{array}$ & $\begin{array}{l}6.17 \\
\sigma=0.78\end{array}$ \\
\hline $\mathrm{Zn}(\mathrm{mg} / \mathrm{kg})$ & $\begin{array}{l}3804 \\
\sigma=22.8\end{array}$ & $\begin{array}{l}23,038 \\
\sigma=5.78\end{array}$ \\
\hline $\mathrm{Cu}(\mathrm{mg} / \mathrm{kg})$ & $\begin{array}{l}197 \\
\sigma=6.1\end{array}$ & $\begin{array}{l}526 \\
\sigma=2.11\end{array}$ \\
\hline $\mathrm{Ni}(\mathrm{mg} / \mathrm{kg})$ & $\begin{array}{l}80.0 \\
\sigma=1.69\end{array}$ & $\begin{array}{l}142 \\
\sigma=0.62\end{array}$ \\
\hline $\mathrm{Cd}(\mathrm{mg} / \mathrm{kg})$ & $\begin{array}{l}8.0 \\
\sigma=0.97\end{array}$ & $\begin{array}{l}0.62 \\
\sigma=0.74\end{array}$ \\
\hline $\mathrm{Cr}(\mathrm{mg} / \mathrm{kg})$ & $\begin{array}{l}86.0 \\
\sigma=1.0\end{array}$ & $\begin{array}{l}125 \\
\sigma=0.52\end{array}$ \\
\hline $\mathrm{Pb}(\mathrm{mg} / \mathrm{kg})$ & $\begin{array}{l}61.0 \\
\sigma=11.8\end{array}$ & $\begin{array}{l}4.19 \\
\sigma=0.38\end{array}$ \\
\hline $\mathrm{Hg}(\mathrm{mg} / \mathrm{kg})$ & 0.64 & 0.24 \\
\hline
\end{tabular}

c. $1 \%(\mathrm{~m} / \mathrm{m})$ of total potassium expressed as potassium oxide $\left(\mathrm{K}_{2} \mathrm{O}\right)$.

Heavy metals content in organo-mineral fertilizers cannot exceed the following values:

1. $\mathrm{Cr}-100 \mathrm{mg}$;

2. $\mathrm{Cd}-5 \mathrm{mg}$;

3. $\mathrm{Ni}-60 \mathrm{mg}$,

4. $\mathrm{Pb}-140 \mathrm{mg}$;

5. $\mathrm{Hg}-2 \mathrm{mg}$.

Selected components of OMFs in proportions showed in Fig. 1 were mixed and dried at $105{ }^{\circ} \mathrm{C}$ for $2 \mathrm{~h}$. Next the product was crushed and analyzed. The phase composition of the obtained product was determined with the use of XRD analysis using X'Pert Pro MD PANalytical. The chemical composition of sewage sludge, poultry litter ash and fertilizers were determined with the use of Atomic Absorption Spectroscopy (AAnalyst 300 Perkin Elmer) after digestion in aqua regia and in $\mathrm{H}_{2} \mathrm{SO}_{4}$ in the case of $\mathrm{Ca}$ and $\mathrm{Pb}$ determination in sewage sludge. The total phosphorus content as well as bioavailability of phosphorus were determined by spectrophotometric method according to standards [32, 33]. 
Fig. 1 The composition of organo-mineral fertilizers

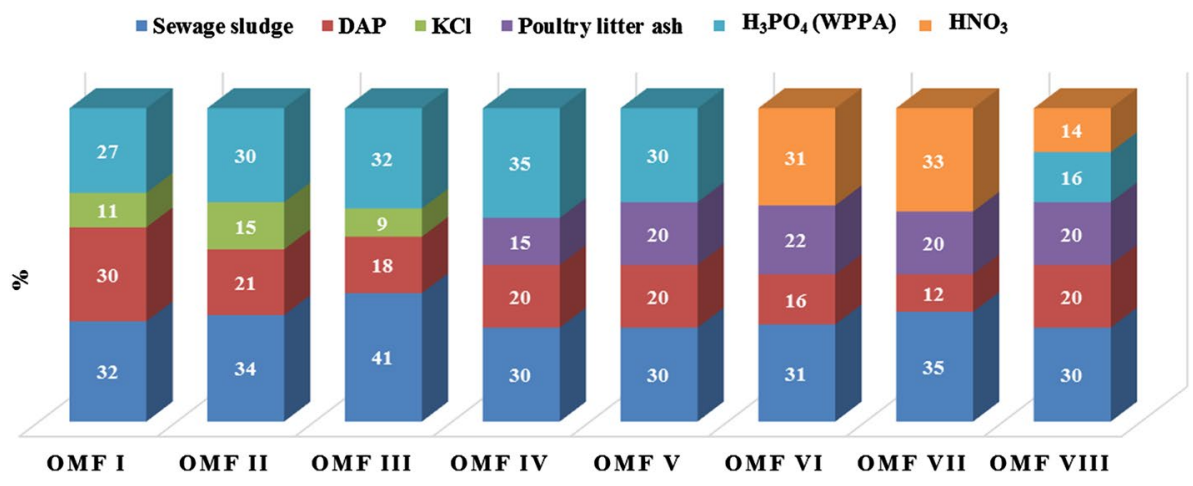

Eight organo-mineral fertilizers compositions were produced. After analyzing their chemical composition two of them with the best characteristics were granulated on a larger scale in a drum granulator with a diameter of $80 \mathrm{~cm}$, an inclination angle of $35^{\circ}$ and rotation 60 revolutions per minute. In addition to chemical characteristics, particle size distribution [34] and bulk density [35] of the obtained products were also determined.

\section{Results and Discussion}

The composition of the obtained organo-mineral fertilizers is presented in Fig. 1. 30-41\% by weight of dried sewage sludge was used in order to limit introducing heavy metals to the product. Diammonium phosphate was added to all the samples in the range of $12-30 \%$ depended on an assumed nutrient content of OMFs. To produce OMF I, OMF II and OMF III potassium chloride was used, in next samples (IV-VIII) it was replaced by poultry litter ash to avoid introducing chloride ions which are undesirable in fertilizers. In OMF I-V WPPA was used, also there were fertilizers produced with nitric acid (OMF VI, VII) and with a mixture of WPPA and nitric acid (OMF VIII).

The $\mathrm{pH}$ value of the obtained OMFs was 6 and higher, which is favourable for soil. The OMF III had the $\mathrm{pH}$ value of 4.02, which is a result of a higher sewage sludge content in this sample (41\%) and accordingly larger share of phosphoric acid added during fertilizer production.

Crystalline phases in the obtained products OMF I-III were identified as monoammonium phosphate, ammonium chloride, potassium chloride and silica, which is evidence of chemical reactions occurring during the fertilization process. In OMF IV and V diammonium phosphate and silica were determined. Monoammonium phosphate and silica were also observed in OMF VIII. OMF VI and VII were characterized by a low degree of crystallinity.

The chemical composition of organo-mineral fertilizers is presented in Table 2. The obtained products are characterized by a high content of nutrients. In OMF VI and OMF VII the total phosphorus content is lower; it is caused by using nitric acids during the preparation process. The potassium content varies between $6.67-10.27 \%$ and depends on the amount of $\mathrm{KCl}$ or poultry litter ash added to the mixture. OMFs also have a high calcium content. This value is increased in OMF IV-VIII and is caused by adding of poultry litter ash rich in $\mathrm{Ca}$. The same tendency is observed in the case of $\mathrm{Mg}$. The $\mathrm{N}$ content in fertilizers is generally sourced from sewage diammonium phosphate and sewage sludge, in OMF VI-VIII also from nitric acid.

The heavy metals content determines whether fertilizers are suitable for agricultural use. The contents of $\mathrm{Ni}$ and $\mathrm{Pb}$ in organo-mineral fertilizers derived from sewage sludge do not exceed the limited values $(60$ and $140 \mathrm{mg} /$ $\mathrm{kg}$, respectively), however the products have high contents of $\mathrm{Cd}$ and $\mathrm{Cr}$. In the case of OMFs I-V, the Cd content is 206-292\% higher than permissible values; $\mathrm{Cr}$ is higher than recommended values by $2-3$ times. OMF VI and OMF VII where nitric acid was used as a binding agent conform to the requirements of Polish regulation related to organomineral fertilizers. The $\mathrm{Cd}$ and $\mathrm{Cr}$ contents in OMF VIII with a mixture of phosphoric and nitric acids also exceed permissible values.

Figures 2 and 3 show the share of constituents of fertilizers concerning the $\mathrm{Cr}$ and $\mathrm{Cd}$ content. The largest load of contaminants in OMFs originated from phosphoric acid (WPPA). $45-72 \%$ of Cr present in organo-mineral fertilizers originated from WPPA. In the case of $\mathrm{Cd}$, phosphoric acid introduces $94-98 \%$ of Cd to products. The quality of WPPA depends on a type of phosphate rocks and sulphuric acids which are used for its decomposition and production technology. During the technological process $50-70 \%$ of $\mathrm{Cd}$ and $70-97 \%$ of $\mathrm{Cr}$ pass to the acid from phosphate ores. In addition, $\mathrm{Fe}, \mathrm{Al}, \mathrm{Zn}, \mathrm{Cu}, \mathrm{V}, \mathrm{U}$ and $\mathrm{As}$ [22] exhibit a high degree of leaching. As WPPA is generally used for inorganic fertilizers, it is necessary to select resources with low contaminants content in order to reduce the introduction of heavy metals to fertilizers.

It is useful to know the amount of available phosphorus in fertilizers to ensure sufficient dissolving of fertilizers 
Table 2 The chemical composition of OMFs

\begin{tabular}{|c|c|c|c|c|c|c|c|c|}
\hline & OMF I & OMF II & OMF III & OMF IV & OMF V & OMF VI & OMF VII & OMF VIII \\
\hline $\mathrm{N}(\%)$ & $\begin{array}{l}7.81 \\
\sigma=0.78\end{array}$ & $\begin{array}{l}5.99 \\
\sigma=1.0\end{array}$ & $\begin{array}{l}5.67 \\
\sigma=0.56\end{array}$ & $\begin{array}{l}5.60 \\
\sigma=0.45\end{array}$ & $\begin{array}{l}5.59 \\
\sigma=0.91\end{array}$ & $\begin{array}{l}9.26 \\
\sigma=1.4\end{array}$ & $\begin{array}{l}8.88 \\
\sigma=0.87\end{array}$ & $\begin{array}{l}7.61 \\
\sigma=0.54\end{array}$ \\
\hline $\mathrm{P}_{2} \mathrm{O}_{5}(\%)$ & $\begin{array}{l}32.98 \\
\sigma=0.75\end{array}$ & $\begin{array}{l}31.09 \\
\sigma=0.85\end{array}$ & $\begin{array}{l}30.84 \\
\sigma=0.30\end{array}$ & $\begin{array}{l}35.30 \\
\sigma=0.83\end{array}$ & $\begin{array}{l}33.68 \\
\sigma=0.16\end{array}$ & $\begin{array}{l}18.27 \\
\sigma=0.20\end{array}$ & $\begin{array}{l}14.32 \\
\sigma=0.03\end{array}$ & $\begin{array}{l}29.94 \\
\sigma=0.44\end{array}$ \\
\hline $\mathrm{K}_{2} \mathrm{O}(\%)$ & $\begin{array}{l}6.67 \\
\sigma=0.43\end{array}$ & $\begin{array}{l}9.07 \\
\sigma=0.01\end{array}$ & $\begin{array}{l}5.49 \\
\sigma=0.12\end{array}$ & $\begin{array}{l}7.02 \\
\sigma=0.08\end{array}$ & $\begin{array}{l}9.34 \\
\sigma=0.03\end{array}$ & $\begin{array}{l}10.27 \\
\sigma=0.12\end{array}$ & $\begin{array}{l}9.35 \\
\sigma=0.19\end{array}$ & $\begin{array}{l}9.34 \\
\sigma=1.1\end{array}$ \\
\hline $\mathrm{Ca}(\mathrm{g} / \mathrm{kg})$ & $\begin{array}{l}11.09 \\
\sigma=0.61\end{array}$ & $\begin{array}{l}10.57 \\
\sigma=0.48\end{array}$ & $\begin{array}{l}15.00 \\
\sigma=0.03\end{array}$ & $\begin{array}{l}23.19 \\
\sigma=0.12\end{array}$ & $\begin{array}{l}28.41 \\
\sigma=0.74\end{array}$ & $\begin{array}{l}33.89 \\
\sigma=0.01\end{array}$ & $\begin{array}{l}31.99 \\
\sigma=0.96\end{array}$ & $\begin{array}{l}33.99 \\
\sigma=0.88\end{array}$ \\
\hline $\mathrm{Mg}(\mathrm{g} / \mathrm{kg})$ & $\begin{array}{l}4.84 \\
\sigma=0.89\end{array}$ & $\begin{array}{l}4.61 \\
\sigma=0.54\end{array}$ & $\begin{array}{l}5.82 \\
\sigma=0.32\end{array}$ & $\begin{array}{l}16.17 \\
\sigma=0.96\end{array}$ & $\begin{array}{l}17.71 \\
\sigma=1.6\end{array}$ & $\begin{array}{l}18.86 \\
\sigma=0.08\end{array}$ & $\begin{array}{l}15.56 \\
\sigma=0.05\end{array}$ & $\begin{array}{l}18.57 \\
\sigma=2.52\end{array}$ \\
\hline $\mathrm{Zn}(\mathrm{g} / \mathrm{kg})$ & $\begin{array}{l}0.91 \\
\sigma=0.007\end{array}$ & $\begin{array}{l}4.04 \\
\sigma=0.068\end{array}$ & $\begin{array}{l}1.17 \\
\sigma=0.046\end{array}$ & $\begin{array}{l}1.98 \\
\sigma=0.056\end{array}$ & $\begin{array}{l}2.21 \\
\sigma=0.038\end{array}$ & $\begin{array}{l}2.25 \\
\sigma=0.055\end{array}$ & $\begin{array}{l}2.35 \\
0.055\end{array}$ & $\begin{array}{l}1.32 \\
\sigma=0.058\end{array}$ \\
\hline $\mathrm{Fe}(\mathrm{g} / \mathrm{kg})$ & $\begin{array}{l}8.91 \\
\sigma=0.01\end{array}$ & $\begin{array}{l}10.07 \\
\sigma=0.39\end{array}$ & $\begin{array}{l}10.97 \\
\sigma=0.43\end{array}$ & $\begin{array}{l}9.95 \\
\sigma=0.09\end{array}$ & $\begin{array}{l}10.26 \\
\sigma=0.04\end{array}$ & $\begin{array}{l}8.28 \\
\sigma=0.06\end{array}$ & $\begin{array}{l}8.58 \\
\sigma=0.13\end{array}$ & $\begin{array}{l}8.85 \\
\sigma=0.11\end{array}$ \\
\hline $\mathrm{Cu}(\mathrm{g} / \mathrm{kg})$ & $\begin{array}{l}0.112 \\
\sigma=0.0012\end{array}$ & $\begin{array}{l}0.124 \\
\sigma=0.0016\end{array}$ & $\begin{array}{l}0.147 \\
\sigma=0.0004\end{array}$ & $\begin{array}{l}0.280 \\
\sigma=0.0003\end{array}$ & $\begin{array}{l}0.243 \\
\sigma=0.0016\end{array}$ & $\begin{array}{l}0.309 \\
\sigma=0.0024\end{array}$ & $\begin{array}{l}0.295 \\
\sigma=0.0014\end{array}$ & $\begin{array}{l}0.274 \\
\sigma=0.0010\end{array}$ \\
\hline $\mathrm{Cd}(\mathrm{mg} / \mathrm{kg})$ & $\begin{array}{l}10.32 \\
\sigma=0.43\end{array}$ & $\begin{array}{l}12.28 \\
\sigma=0.36\end{array}$ & $\begin{array}{l}12.68 \\
\sigma=0.39\end{array}$ & $\begin{array}{l}13.03 \\
\sigma=1.2\end{array}$ & $\begin{array}{l}14.62 \\
\sigma=0.15\end{array}$ & $\begin{array}{l}1.60 \\
\sigma=0.059\end{array}$ & $\begin{array}{l}1.54 \\
\sigma=0.14\end{array}$ & $\begin{array}{l}7.46 \\
\sigma=0.12\end{array}$ \\
\hline $\mathrm{Pb}(\mathrm{mg} / \mathrm{kg})$ & $\begin{array}{l}18.88 \\
\sigma=0.36\end{array}$ & $\begin{array}{l}20.39 \\
\sigma=0.75\end{array}$ & $\begin{array}{l}24.59 \\
\sigma=1.3\end{array}$ & $\begin{array}{l}26.16 \\
\sigma=1.7\end{array}$ & $\begin{array}{l}24.15 \\
\sigma=0.58\end{array}$ & $\begin{array}{l}12.67 \\
\sigma=0.87\end{array}$ & $\begin{array}{l}10.80 \\
\sigma=0.25\end{array}$ & $\begin{array}{l}15.17 \\
\sigma=0.64\end{array}$ \\
\hline $\mathrm{Cr}(\mathrm{mg} / \mathrm{kg})$ & $\begin{array}{l}167.9 \\
\sigma=0.17\end{array}$ & $\begin{array}{l}196.9 \\
\sigma=2.6\end{array}$ & $\begin{array}{l}210.5 \\
\sigma=4.7\end{array}$ & $\begin{array}{l}228.8 \\
\sigma=14.2\end{array}$ & $\begin{array}{l}246.0 \\
\sigma=6.9\end{array}$ & $\begin{array}{l}81.5 \\
\sigma=0.26\end{array}$ & $\begin{array}{l}77.0 \\
\sigma=4.2\end{array}$ & $\begin{array}{l}131.4 \\
\sigma=0.25\end{array}$ \\
\hline $\mathrm{Ni}(\mathrm{mg} / \mathrm{kg})$ & $\begin{array}{l}31.24 \\
\sigma=0.55\end{array}$ & $\begin{array}{l}39.08 \\
\sigma=0.12\end{array}$ & $\begin{array}{l}35.42 \\
\sigma=0.56\end{array}$ & $\begin{array}{l}50.20 \\
\sigma=0.06\end{array}$ & $\begin{array}{l}55.21 \\
\sigma=0.50\end{array}$ & $\begin{array}{l}47.72 \\
\sigma=0.06\end{array}$ & $\begin{array}{l}45.11 \\
\sigma=0.21\end{array}$ & $\begin{array}{l}50.73 \\
\sigma=0.41\end{array}$ \\
\hline
\end{tabular}

Fig. 2 The share of constituents introducing $\mathrm{Cr}$ to organomineral fertilizers

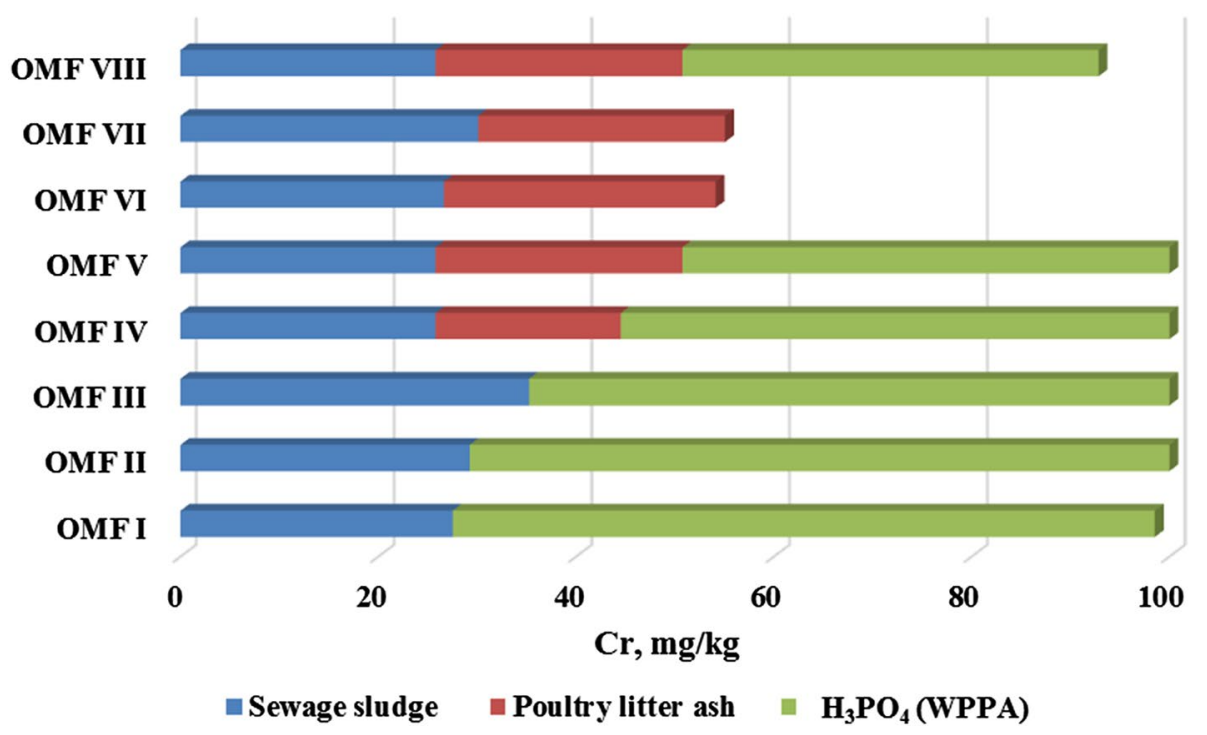

and prevent soil and water pollution. In Fig. 4 the solubility of phosphorus compounds in water and neutral ammonium citrate $(\mathrm{pH} 7)$ is presented. In OMFs with WPPA the solubility in water accounts for $63-90 \%$ of total phosphorus content. The solubility of phosphorus compounds in ammonium citrate is higher -73 to $100 \%$. Its lower solubility in water was found for fertilizers made with use of nitric acids (36-45\%), solubility in ammonium citrate varies between 82 and $88 \%$ of total phosphorus content.

Two compositions of OMFs from sewage sludge with the best characteristics (low heavy metals and high NPK content) were granulated on the larger scale and analyzed. Granular fertilizers supply uniform release of nutrients; in addition they are easy to spread, transport and store. $30 \%$ 
Fig. 3 The share of constituents introducing $\mathrm{Cd}$ to organomineral fertilizers
Fig. 4 The solubility of phosphorus compounds in organomineral fertilizers
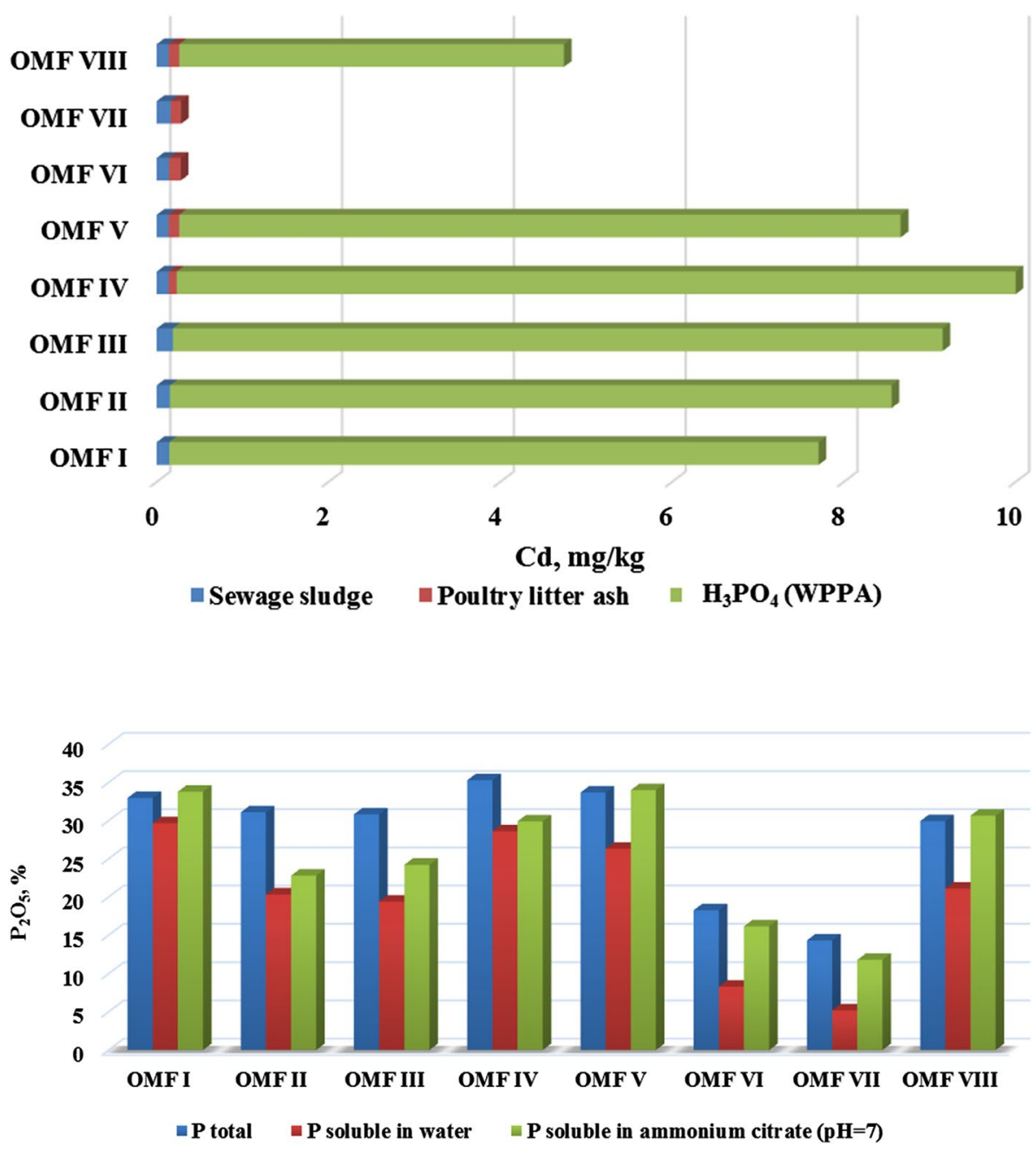

of dried sewage sludge with poultry litter ash and DAP were mixed with a mixture of WPPA/nitric acid in granulation process I and with nitric acid in granulation process II (Table 3).

In granulation process I fertilizers with a wide grain size range (Fig. 5) were obtained. It can be attributed to that fact that the mixture of acids was added manually, while during granulation II the pump was used for feeding acid; it allowed to obtain fertilizers with a grain size of $8-10 \mathrm{~mm}$. The size distribution of products is presented in Fig. 6. Bulk density of sewage-derived fertilizers is $0.56 \mathrm{~kg} / \mathrm{dm}^{3}$ for granular OMFs I and $0.50 \mathrm{~kg} / \mathrm{dm}^{3}$ for granular OMFs II.

The results of chemical analyses of granular fertilizers are presented in Table 4. As expected, the nutrient content of the obtained fertilizers I and II slightly differs, which is connected with a different ratio of components. The solubility of phosphorus compounds in water was 56 and $51 \%$, whereas in neutral ammonium citrate -96 and $100 \%$ for OMFs I and OMFs II, respectively. It should be
Table 3 The composition of granular OMFs

Sewage sludge Poultry DAP(\%) WPPA $\mathrm{HNO}_{3}$ litter ash

\begin{tabular}{llllll}
\hline Granulation I & 30 & 20 & 20 & 10 & 20 \\
Granulation II & 30 & 22 & 16 & - & 32 \\
\hline
\end{tabular}

highlighted that a part of $\mathrm{P}$ and $\mathrm{N}$ in organo-mineral fertilizers is in the form of organic fraction. It makes sewagederived fertilizers long-action products.

The heavy metals content of granular OMFs I does not excess permissible values except for Cr. WPPA is responsible for a high $\mathrm{Cr}$ content in fertilizers. The amount of WPPA should be reduced in order to obtain a product fulfilling the requirements. In granular OMFs II concentrations of heavy metals are below the recommended values. The Hg content is below the detection limit in both fertilizer samples. 

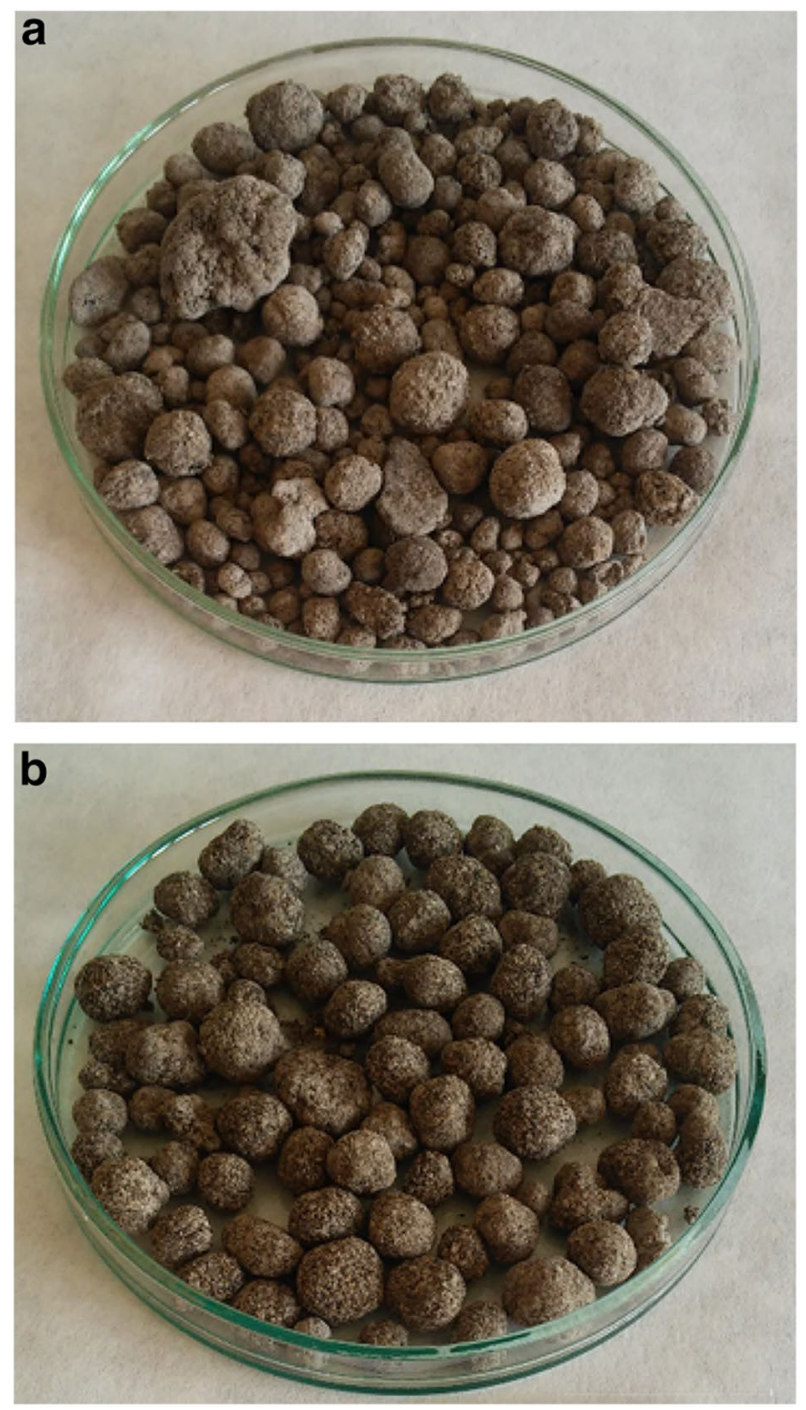

Fig. 5 Pictures of granular organo-mineral fertilizer I (a) and II (b)
Granular OMFs II complies with Polish standards concerning organo-mineral fertilizers with respect to nutrients and heavy metals content. The material balance was calculated for OMFs II (Table 5).

Loses in the granulation process amount to $9.4 \%$, which can be attributed to a relatively large disc of the granulator.

The simplified economic analysis of granular OMF II was made. The approximate cost of fertilizer derived from dried sewage sludge was calculated and compared with the production cost of fertilizers in which the amounts of macronutrients introduced with waste (sewage sludge, poultry litter ash) $13.56 \mathrm{~kg} \mathrm{~N}, 56.32 \mathrm{~kg} \mathrm{P}_{2} \mathrm{O}_{5}$ and $53.45 \mathrm{~kg}$ $\mathrm{K}_{2} \mathrm{O}$ in $1 \mathrm{t}$ of fertilizer were replaced by conventional fertilizers. In the first case diammonium phosphate, superphosphate and potassium chloride were used, while in the second option ammonium nitrate was selected as a nitrogen source. In Tables 6 and 7 the prices of components from Polish producers and estimated costs of fertilizers are presented.

The estimated profit in the production of fertilizers from sewage sludge is $50.45 \%$ in the first case and $48.19 \%$ in the second one. In addition, the profit from waste utilization was not taken into account. According to Waste Directive [36] a producer of waste should utilize it in appropriate way, which is connected with additional costs. Due to this fact, producers of sewage sludge based fertilizers will get profits using sewage sludge as secondary raw materials.

Such sewage sludge based fertilizers fulfilling requirements concerning heavy metals content can get the market entry based on Fertilizer Directive 2003/2003/EC [33] and Regulation of the Minister of Agriculture and Rural Development [31] but only within Poland. The documents include lists of organizational units which are authorized to conduct physical, physico-chemical, biological and agronomic tests regarding the quality requirements and requirements related to heavy metals content in fertilizers. Based
Fig. 6 Size distribution of organo-mineral fertilizers

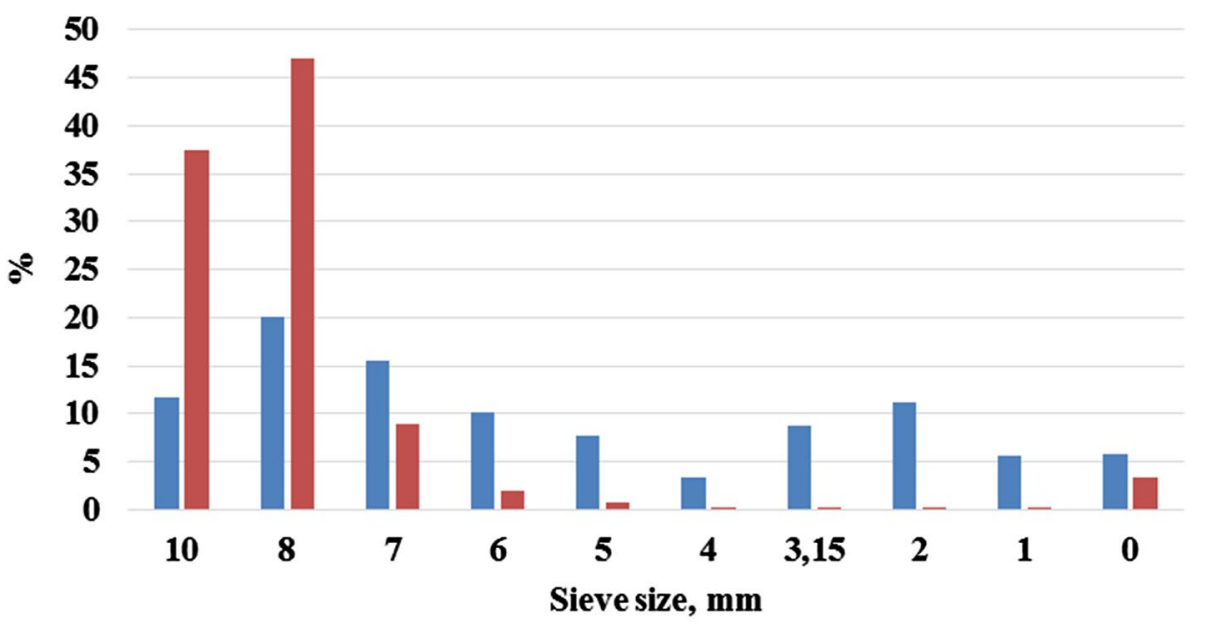

a Granular OMFs I $\quad$ Granular OMFs II 
Table 4 The chemical characterization of granular organo-mineral fertilizers

\begin{tabular}{lll}
\hline & Granular OMF I & Granular OMF II \\
\hline $\mathrm{N}(\%)$ & 6.08 & 6.80 \\
& $\sigma=0.42$ & $\sigma=0.58$ \\
$\mathrm{P}_{2} \mathrm{O}_{5}(\%)$ & 25.2 & 19.8 \\
& $\sigma=0.41$ & $\sigma=0.16$ \\
$\mathrm{~K}_{2} \mathrm{O}(\%)$ & 5.91 & 6.21 \\
& $\sigma=0.42$ & $\sigma=0.18$ \\
$\mathrm{Ca}(\mathrm{g} / \mathrm{kg})$ & 36.32 & 40.49 \\
& $\sigma=0.25$ & $\sigma=0.26$ \\
$\mathrm{Mg}(\mathrm{g} / \mathrm{kg})$ & 14.02 & 15.08 \\
& $\sigma=0.19$ & $\sigma=0.20$ \\
$\mathrm{Zn}(\mathrm{g} / \mathrm{kg})$ & 1.276 & 1.978 \\
& $\sigma=0.01$ & $\sigma=0.01$ \\
$\mathrm{Fe}(\mathrm{g} / \mathrm{kg})$ & 9.494 & 9.954 \\
& $\sigma=0.12$ & $\sigma=0.08$ \\
$\mathrm{Cu}(\mathrm{g} / \mathrm{kg})$ & 0.2831 & 0.3191 \\
$\mathrm{Cd}(\mathrm{mg} / \mathrm{kg})$ & $\sigma=0.009$ & 0.009 \\
$\mathrm{~Pb}(\mathrm{mg} / \mathrm{kg})$ & 3.060 & $<\mathrm{LOD}$ \\
& $\sigma=0.07$ & \\
$\mathrm{Cr}(\mathrm{mg} / \mathrm{kg})$ & 50.61 & 45.11 \\
$\mathrm{Ni}(\mathrm{mg} / \mathrm{kg})$ & $\sigma=2.0$ & $\sigma=0.61$ \\
& 103.8 & 65.50 \\
& $\sigma=11.2$ & $\sigma=2.6$ \\
& 40.79 & 37.44 \\
& $\sigma=1.1$ & $\sigma=0.18$ \\
\hline & &
\end{tabular}

Table 5 Material balance of granular OMFs II production

\begin{tabular}{llll}
\hline Revenue (\%) & \multicolumn{3}{c}{ Expense (\%) } \\
\hline Sewage sludge & 27.8 & Granulate & 34.5 \\
Poultry litter ash & 20.4 & Not granulated fraction & 37.8 \\
Diammonium phosphate & 14.8 & Evaporated water & 18.3 \\
$\mathrm{HNO}_{3}(65 \%)$ & 28.9 & Losses & 9.4 \\
Water & 8.1 & & \\
Sum & 100 & Sum & 100 \\
\hline
\end{tabular}

Table 6 Prices of components

\begin{tabular}{lc}
\hline Component & Price, PLN/t (€/t) \\
\hline Diammonium phosphate (DAP), "Police" & $1755(404.38)$ \\
Ammonium nitrate, "Puławy" & $1125(259.22)$ \\
Potassium chloride, "Luvena" & $1550(357.14)$ \\
Superphosphate, "Fosforyty" & $1370(315.67)$ \\
Nitric acid (55\%) "Branntag" & $782(180.18)$ \\
\hline
\end{tabular}

on an opinion of approved organizational units the Minister of Agriculture issues permission for fertilizer's entry onto the market.

There is a known Polish patented technology of granular organo-mineral fertilizer based on sewage sludge "Oscar"
[37], which got permission for entering the market. The fertilizer is produced by mixing activated sludge with $25 \%$ of dried solids, magnesite and concentrated sulphuric acid, which results in $16 \%$ of $\mathrm{MgO}$ and $23 \%$ of $\mathrm{SO}_{3}$ content in obtained products. In comparison with "Oscar" the granular organo-mineral fertilizer obtained in this paper is characterized by high NPK values (7:20:6) and can be used as a self-contained and complete fertilizer. Beside, the utilization of poultry litter ash is also included in the technology.

Using sewage sludge for fertilizers production leads to reduction in the amount of waste, ensures recycling of nutrients and organic matter to the soil and improves usage of natural resources, which is in the line with sustainable development. It should be mentioned that not all the sewage sludge can be used as a component of fertilizers, it depends on its quality. The sewage sludge management process should be developed for each waste water treatment plant.

\section{Conclusions}

The agricultural use of sewage sludge is one of the most controversial topics in the EU. The prohibition of sewage sludge storage and tightening of European regulations make challenges for sewage sludge management. On the other hand, proposals of the European Commission regarding new organic and waste-based fertilizers encourage using sewage sludge for fertilizer production as a valuable source of phosphorus and nitrogen, as well as organic matter. The paper has shown that the production of sewagederived fertilizers can be justified.

Organo-mineral fertilizers based on dried sewage sludge were produced with adding diammonium phosphate, potassium chloride and poultry litter ash in different ratios in order to increase the nutrients content in the product and WPPA or/and nitric acids as a binding agent. Chemical analyses have shown that the obtained fertilizers have a high nutrient content fulfilling Polish requirements, while adding WPPA introduced a large amount of $\mathrm{Cr}$ and $\mathrm{Cd}$, which in turn led to the exceeding of permissible values of these metals in organo-mineral fertilizers. Granular organomineral fertilizers were produced by mixing dried sewage sludge, poultry litter ash, DAP and $\mathrm{KCl}$ in proportion 30:20:20 and 30:22:16 by weight; the mixture of WPPA/ nitric acid in composition I and nitric acids in composition II were used. Products include approximately $6 \%$ of $\mathrm{N}, 19.8-25.2 \%$ of $\mathrm{P}_{2} \mathrm{O}_{5}$ and 5.91-6.21\% of $\mathrm{K}_{2} \mathrm{O}$. Fertilizers containing the mixture of WPPA and nitric acids have a slightly higher value of $\mathrm{Cr}$ than the recommended value. Reducing the amount of WPPA during fertilizer production can decrease the $\mathrm{Cr}$ content in the product. Fertilizers with nitric acid comply with requirements regarding 
Table 7 Estimated costs of organo-mineral fertilizer derived from sewage sludge and conventional fertilizers

\begin{tabular}{|c|c|c|c|c|c|}
\hline \multirow[t]{2}{*}{ Component } & \multicolumn{5}{|c|}{ Fertilizer based on sewage sludge } \\
\hline & Mass, kg & \multicolumn{4}{|l|}{ Price, $€$} \\
\hline Dried sewage sludge & 300 & \multicolumn{4}{|l|}{0} \\
\hline Poultry litter ash & 220 & \multicolumn{4}{|l|}{0} \\
\hline Diammonium phosphate (DAP) & 160 & \multicolumn{4}{|l|}{88.96} \\
\hline Nitric acid (100\%) & 320 & \multicolumn{4}{|l|}{104.70} \\
\hline Costs & 1000 & \multicolumn{4}{|l|}{193.66} \\
\hline \multicolumn{6}{|l|}{ Mineral blending fertilizers } \\
\hline \multicolumn{3}{|l|}{ Option I } & \multicolumn{3}{|l|}{ Option II } \\
\hline Component & Mass, $\mathrm{kg}$ & Price, $€$ & Component & Mass, $\mathrm{kg}$ & Price, $€$ \\
\hline Diammonium phosphate (DAP) & 235.33 & 119.42 & $\begin{array}{l}\text { Diammonium phosphate } \\
\text { (DAP) }\end{array}$ & 160.0 & 88.96 \\
\hline Superphosphate & 54.18 & 17.10 & Ammonium nitrate & 39.88 & 10.34 \\
\hline Potassium chloride & 89.09 & 31.82 & Potassium chloride & 89.09 & 31.82 \\
\hline \multirow[t]{2}{*}{ Nitric acid $(100 \%)$} & 320.00 & 104.70 & Superphosphate & 140.80 & 44.45 \\
\hline & & & Nitric acid (100\%) & 320.00 & 104.70 \\
\hline \multirow[t]{2}{*}{ Costs } & 698.60 & 273.04 & Costs & 749.77 & 280.27 \\
\hline & 1000 & 390.84 & & 1000 & 373.81 \\
\hline
\end{tabular}

nutrients and heavy metals content. The obtained product was characterized by a uniform grain size (10 mm-37.4\% and $8 \mathrm{~mm}-47.1 \%$ ). A simplified economic analysis showed that the profits from sewage sludge based fertilizers in comparison with conventional fertilizers can amount to $50.45 \%$.

The results of research work showed that sewage sludge should be treated as raw materials and used for organomineral fertilizers production. Such an approach is a step towards recycling society in line with the CE policy.

Open Access This article is distributed under the terms of the Creative Commons Attribution 4.0 International License (http:// creativecommons.org/licenses/by/4.0/), which permits unrestricted use, distribution, and reproduction in any medium, provided you give appropriate credit to the original author(s) and the source, provide a link to the Creative Commons license, and indicate if changes were made.

\section{References}

1. Milieu Ltd., WRc and RPA: Environmental economic and social impacts of the use of sewage sludge on land. Final Report. Part III: Project Interim Reports (2010).

2. Tiruneh, A.T., Faridan, A.O., Mtshali, J.S.: Evaluation of the risk of heavy metals in sewage sludge intended for agricultural application in Swaziland. IJEST 5(1), 197-206 (2014)

3. Andreoli, C.V., Sperling, M., Fernandes, F.: Sludge treatment and disposal. Biological wastewater treatment series, vol 6, IWA publishing, London (2007)

4. Latare, A.M., Kumar, O., Singh, S., Gupta, A.: Direct and residual effect of sewage sludge on yield, heavy metals content and soil fertility under rice-wheat system. Ecol. Eng. 69, 17-24 (2014)

5. Clarke, B.O., Smith, S.R.: Review of 'emerging' organic pollutants in biosolids and assessment of international research priorities for the agricultural use and biosolids. Environ. Int. 37, 226247 (2011)

6. Kotowska, U., Żalikowski, M., Isidorov, V.A.: HS-SPME/ GC-MS analysis of volatile and semi-volatile organic compounds emitted from municipal sewage sludge. Environ. Monit. Assess. 184, 2893-2907 (2012)

7. Pająk, T.: Thermal treatment as sustainable sewage sludge management. Environ. Protect. Eng. 39(2), 41-53 (2013)

8. Kelessidis, A., Stasinakis, A.S.: Comparative study of the methods used for treatment and final disposal of sewage sludge in European countries. Waste Manag. 32, 1186-1195 (2012)

9. Mathews, J.A., Tan, H.: Lessons from China. Nature. 531, 440 442 (2016)

10. European Resource Efficiency Platform (EREP): Manifesto \& policy recommendations (2012)

11. Dawson, C.J., Hilton, J.: Fertilizer availability in a resource-limited world: production and recycling of nitrogen and phosphorus. Food Pol. 36, S14-S22 (2011)

12. Scholz, R.W., Ulrich, A.E., Eilitta, M., Roy, A.: Sustainable use of phosphorus: finite resource. Sci. Total Environ. 461-462, 799-803 (2013)

13. Lee, R.: The outlook for population growth. Science. 333, 569$573(2011)$

14. http://p-rex.eu/

15. Xu, G. Analysis of sewage sludge recovery system in EU-in perspectives of nutrients and energy recovery efficiency, and environmental impacts, Norwegian University of Science and Technology, Trondheim (2014)

16. Wang, X., Chen, T., Ge, Y., Jia, Y.: Studies on land application of sewage sludge and its limiting factors. J. Hazard. Mater. 160(2-3), 554-558 (2008)

17. Rizzardini, C.B., Goi, D.: Sustainability of domestic sewage sludge disposal. Sustainability. 6, 2424-2434 (2014) 
18. Central Statistical Office, Environmental protection.: Warszawa (2015) (in polish).

19. Environmental protection.: Council Directive of 12 June 1986 on the protection of the environment, and in particular of the soil, when sewage sludge is used in agriculture (86/278/EEC).

20. Commission of European Communities.: Council Directive of 21 May 1991 concerning urban waste-water treatment (91/271/ EEC).

21. Schowanek, D., Carr, R., David, H., Douben, P., Hall, J., Kirchmann, H., Patria, L., Sequi, P., Smith, S., Webb, S.: A risk-based technology for deriving quality standards for organic contaminants in sewage sludge for use in agriculture-conceptual framework. Regul. Toxicol. Pharm. 40, 227-251 (2004)

22. Minini, G., Blanch, A.R., Lucena, F., Bersseli, S.: EU policy on sewage sludge utilization and perspectives on new approaches on sewage sludge. Environ. Sci. Pollut. Res. 22, 7361-7374 (2015)

23. Harrison, E.Z., Oakes, S.R., Hysell, L., Hay, A.: Organic chemicals in sewage sludge. Sci. Total Environ. 367, 481-497 (2006)

24. Aparicio, I., Santos, J.L., Alonso, E.: Limitation of the concentration of organic pollutants in sewage sludge for agricultural purposes: A case study in South Spain. Waste Manag. 29, 17471753 (2009)

25. Butkowskyi, A., Ni, G., Leal, L.H., Rijnaarts, H.H.M., Zeeman, G.: Mitigation of micropollutants for black water application in agriculture via composting of anaerobic sludge. J. Hazard. Mater. 303, 41-47 (2016)

26. Chen, X., Vollertsen, J., Nielsen, J.L., Gieraltowska-Dal, A., Bester, K.: Degradation of PPCPs in activated sludge from different WWTPs in Denmark. Ecotoxicology. 24, 2073-2080 (2015)

27. Boix, C., Ibanez, M., Fabregat-Safont, D., Morales, E., Pastor, L., Sancho, J.V., Sanchez-Ramirez, J.E. Hernandez, F.:
Behaviour of emerging contaminants in sewage sludge after anaerobic digestion. Chemosphere. 163, 296-304 (2016)

28. Buckwell, A., Nadeu, E.: Nutrient Recovery and Reuse (NRR) in European agriculture. A review of the issues, opportunities and actions. Brussels (2016)

29. Commission of European Communities (EC) No 1069/2009 and (EC) No 1107/2009, 2016/0084 (COD)

30. Grzmil, B., Kic, B., Zienkiewicz, M., Podolak, A.: Effect of raw materials quality on the content of contaminations in raw phosphoric acid from wet process. Chem. Ind. 90/8, 1535-1540 (2011) (in polish)

31. Proposal for a Regulation of the European Parliament and of the Council laying down rules on the making available on the market of CE marked fertilising products and amending Regulations, 18, 2008 (in polish).

32. PN-88/C-87015. Artificial fertilizers. The methods of phosphorus determination (in polish)

33. Regulation (EC) No 20032003 of the European Parliament and of the Council of 13 October 2003 relating to fertilizers.

34. PN-93/C- 84300/27. Test methods for phosphate salt - sodium tripolyphosphate and technical sodium pyrophosphate - Determination of particle size distribution by mechanical sieving (in polish)

35. PN-80/C- 04532. Determination of bulk density (in polish)

36. Regulation of the Minister of Agriculture and Rural Development dated on July Directive dated on December 14, 2012 (in polish)

37. Michalak, P.P., Romiński, M.R., Pawłowski, W.K., Czerwiński, K., Knieć, D.: The way of fertilizer production from sewage sludge after biological waste water treatment, PL 210311B1 (2009) (in polish) 